\title{
The fatty acid composition of longissimus lumborum muscle of suckling and early- weaned dual-purpose wool/meat lambs
}

\author{
Aurelia Radzik-Rant, Witold Rant, Agnieszka Rozbicka-Wieczorek and Ewa Kuźnicka \\ Department of Animal Breeding, Faculty of Animal Science, Warsaw University of Life Sciences, Warsaw, Poland
}

\begin{abstract}
Twenty-four dual purpose (wool/meat) suckling and early weaned ram lambs were used to study the fatty acid profile in intramuscular fat of longissimus lumborum muscle and lipid oxidation in blood serum. At 60 days of age 12 rams were slaughtered as suckling lambs. The other 12 early weaned and fed according to standards by grass hay and concentrate, and slaughtered at 90 days of age. Suckling lambs had more polyunsaturated fatty acids $(P \leq 0.01)$ than early-weaned lambs. Younger lambs obtained also higher values of $n-3$ fatty acids $(P \leq 0.01)$ and lower $\mathrm{n}-6 / \mathrm{n}-3$ ratio $(P \leq 0.01)$ appropriate in relation to their contribution to human health. Muscle tissue of early-weaned lambs compared to suckling group was characterised by significantly higher $c 9, \mathrm{t} 11 \mathrm{C} 18: 2$ content $(P \leq 0.01)$, which is desirable in human diet with regard to its peculiarities. The higher amount $(P \leq 0.01)$ of vaccenic acid, which is the substrate for rumenic acid formation, has been observed in early-weaned lambs also.
\end{abstract}

Keywords: suckling lambs, early-weaned lambs, fatty acids

\section{Introduction}

The fatty acid composition plays remarkable role in the definition of quality and nutritional value of meat for human consumption (Williams 2000). Lipid peroxidation is one of the major causes of quality deterioration in raw and cooked meat products. The oxidation of lipids results in the production of compounds, which affect the flavour and colour of meat. The toxicity, mutagenicity and carcinogenicity of malonaldehyde, which is formed during meat oxidation is also known (Pearson et al. 1983, Wood \& Enser 1997).

The fatty acid composition in the diet is very important in relation to consumer health. An unbeneficial fatty acid composition of dietary lipids (saturated fatty acid, n-6 unsaturated fatty acid) was demonstrated to increase the risk to contract coronary heart disease (Kritchevsky 1998, Hu et al. 1999). The polyunsaturated fatty acids (PUFAs), particularly n-3 PUFAs exert beneficial effects against cardiovascular and tumour diseases, inflammatory and immune disorders, and neurological dysfunctions (Fernandez \& Venkatraman 1993, Burns \& Spector 1994, Calder 1998). The conjugated linoleic acids (e.g. c9,t11 C18:2) have the same profitable effect on human health (Khanal \& Dihman 2004). Among ruminant-origin meat, lamb meat can be characterised by comparatively high amounts of beneficial conjugated linoleic acids (Schmid et al. 2006). 
Different factors influence lambs fatty acid profile. It has been shown that fat composition of lamb's tissues may be modified by diet and animal production system (Diaz et al. 2002, Wachira et al. 2002, Rhee et al. 2003). Breed and body weight/age at slaughter can also influence the fatty acids profile of lamb's meat (Cifuni et al. 2000, Marino et al. 2008).

Depending on production system and consumer preferences, lambs can be slaughtered as suckling in light live weight or after weaning and fattening at older age and higher body weight. The fat composition of suckling lambs is mainly related to the fat composition of the milk they consume. The suckling lambs have not yet developed a functional rumen with its corresponding microorganisms, for that reason dietary compounds undergo less intensive ruminal degradation than in weaned lambs (Diaz et al. 2003). The changes in fat metabolism that occur with an increase of age affect nutritional quality of lamb's meat.

The aim of the present study was indication the meat quality and its health value of suckling and early-weaned lambs, on the ground of fatty acid profile in longissimus lumborum muscle.

\section{Material and methods}

\section{Animal treatments}

The experiment has been conducted on dual wool/meat purpose lambs of Polish Lowland sheep. This strain of sheep with good body conformation and meat performance, characterise by high prolificacy (175\%), is reared in central part of Poland and mainly used to slaughter lambs production.

Randomly assigned, 24 single born ram lambs were used in this trial. All animals remained with their dams until two months of age.

The ewes received grass hay $(3.9 \mathrm{MJ} / \mathrm{kg}$ dry matter [DM], $11.8 \%$ crude protein $[C P] / \mathrm{kg} D M$, $29.1 \%$ crude fibre [CF] $/ \mathrm{kg} \mathrm{DM}, 0.94 \%$ ether extract [EE] $/ \mathrm{kg} \mathrm{DM})$ and concentrate $(7.02 \mathrm{MJ} / \mathrm{kg}$ DM, $18 \%$ CP/kg DM, $2.85 \%$ EE/kg DM) containing: oat meal (31\%), wheat meal (23\%), wheat bran (15\%), rape meal (30\%), mineral mixture (1\%).

The lambs from two weeks of age received ad libitum grass hay and concentrate (7.1 MJ/ kg DM, 15.1\% CP/kg DM, 2.68 EE/kg DM) containing: oat meal (31\%), rape meal (16\%), wheat meal (31\%), wheat bran (21\%), mineral mixture (1\%), as well as maternal milk.

At 60 days of age 12 lambs were slaughtered. The other 12 ram lambs weaned and fed according to standards by grass hay and concentrate through the next month. At the age of 90 days lambs were slaughtered. All the animals were individually weighed every two-week interval, and average daily gains were calculated.

Before slaughter lambs were fasted for $12 \mathrm{~h}$ and weighed. Then, taken to an abattoir and slaughtered according to standard commercial procedures. Carcasses were chilled at $4{ }^{\circ} \mathrm{C}$ for $24 \mathrm{~h}$. On the right halves of the carcasses, the samples of longissimus lumborum muscle were taken, vacuum packed and frozen at $-20^{\circ} \mathrm{C}$ until being used for chemical analysis.

The milk samples $(50 \mathrm{ml})$ were collected from ewes at 2 th, 4 th and 8 th week of lactation and stored at $4^{\circ} \mathrm{C}$ for analysis.

The blood for analysis of lipid oxidation was collected from jugular vein of lambs before slaughter. Serum was stored at $-20^{\circ} \mathrm{C}$ before use. 


\section{Analytical procedures}

Fatty acid analysis (meat/milk)

Total lipids in lamb's muscle were extracted according to Folch et al. (1957). Fatty acid methyl esters were prepared according to method given by Kramer et al. (1997). Fatty acid composition of lipids was performed by gas-chromatograph analysis using Hewlett Packard GC 5890 instrument (Hewlett-Packard Company, Palo Alto, CA, USA) equipped with a fused-silica capillary column DB-23 (length $60 \mathrm{~m}$, internal diameter $0.25 \mathrm{~mm}$, film thickness $0.25 \mathrm{~mm}$ ). Operating conditions were: helium flow $1.2 \mathrm{ml} / \mathrm{min}$; a FID detector at $240^{\circ} \mathrm{C}$. The temperature programme of column was: $1 \mathrm{~min}$ at $130^{\circ} \mathrm{C}$, an increase to $170^{\circ} \mathrm{C}$ by $+10^{\circ} \mathrm{C} / \mathrm{min}$, to $215^{\circ} \mathrm{C}$ by $+2.5^{\circ} / \mathrm{min}$, to $230^{\circ} \mathrm{C}$ by $+20 \% \mathrm{~min}$. The fatty acids and fatty acid isomers were identified and quantified via following external FAME standards (Sigma-Aldrich Poland, Poznan, Poland): 18917, 18919, octadecadienoic acid, conjugated methyl ester 0-5632. Results are expressed in g/100 fat.

Lipids of milk were extracted using Röse-Gottlieb method (AOAC 1990). Gas chromatograph analysis was performed as described for meat, although temperature programme for the column was different: $130^{\circ} \mathrm{C}(1 \mathrm{~min})$, to $210^{\circ} \mathrm{C}$ by $+10^{\circ} \mathrm{C} / \mathrm{min}$, to $230^{\circ} \mathrm{C}$ by $+2.5^{\circ} \mathrm{C}$. Identification of fatty acids was performed as described for meat. The fatty acids composition of ewe's milk and concentrate are reported in Table 1 and expressed in $\mathrm{g} / 100 \mathrm{~g}$ fat.

Table 1

Fatty acid composition ( $\mathrm{g} / 100 \mathrm{~g}$ fat) of the feeds consumed by lambs

\begin{tabular}{|c|c|c|c|c|}
\hline Fatty acids & $\begin{array}{c}\text { Ewe's milk at } \\
\text { 2nd week of lactation }\end{array}$ & $\begin{array}{c}\text { Ewe's milk at } \\
\text { 4th week of lactation }\end{array}$ & $\begin{array}{c}\text { Ewe's milk at } \\
\text { 8th week of lactation }\end{array}$ & Concentrate \\
\hline C4:0 & 2.91 & 2.69 & 2.59 & - \\
\hline C6:0 & 2.07 & 1.70 & 1.92 & - \\
\hline C8:0 & 1.37 & 1.28 & 1.29 & - \\
\hline $\mathrm{C} 10: 0$ & 6.29 & 5.49 & 5.57 & - \\
\hline C12:0 & 3.65 & 3.73 & 3.76 & 0.19 \\
\hline C14:0 & 8.49 & 8.63 & 8.80 & 0.19 \\
\hline $\mathrm{C} 16: 0$ & 22.43 & 23.16 & 23.04 & 14.63 \\
\hline C17:0 & 0.93 & 0.92 & 0.95 & 0.10 \\
\hline C18:0 & 11.2 & 12.14 & 11.63 & 1.43 \\
\hline C20:0 & - & - & - & 0.19 \\
\hline C14:1 & 1.05 & 1.05 & 1.07 & - \\
\hline C16:1 & 0.30 & 0.32 & 0.36 & 0.29 \\
\hline C18:1c9 & 22.47 & 22.13 & 22.45 & 30.31 \\
\hline C18:1t11 & 2.14 & 1.95 & 1.98 & - \\
\hline C18:2 n-6 & 2.54 & 2.45 & 2.40 & 41.30 \\
\hline C18:2 c9,t11 & 0.44 & 0.49 & 0.48 & - \\
\hline C18:3 n-3 & 0.66 & 0.70 & 0.70 & 3.35 \\
\hline$C 20: 4 n-6$ & 0.18 & 0.20 & 0.19 & - \\
\hline$C 20: 5 n-3$ & 0.11 & 0.11 & 0.11 & - \\
\hline$C 22: 6 n-3$ & 0.07 & 0.06 & 0.07 & - \\
\hline
\end{tabular}

Fodder analysis

Chemical composition and nutritional value of fodder were analysed according to AOAC standard methods (1990). Lipids from representative sample of concentrate were extracted using the method Folch et al. (1957). Methyl esters were prepared according to the Polish 
standard PN-EN ISO 5509 (2001) using boron trifluoride. Gas chromatograph analysis of fatty acid methyl esters was performed in accordance with PN-EN ISO 5508 (1996) (capillary column BXP 70, length $60 \mathrm{~m}$, internal diameter $0.22 \mathrm{~mm}$, film thickness $0.25 \mathrm{~mm}$ ).

\section{Lipid peroxidation analysis}

Lipid oxidation in serum was assessed by measuring thiobarbituric acid reactive substances (TBARS). The thiobarbituric acid test was performed according to Nair \& Turner (1984). Lipid oxidation is expressed in $\mathrm{nmol}$ TBARS/ml serum.

\section{Statistical analysis}

Least squares procedures were used to analyse lipid content and fatty acid composition based on a linear model that included the effect of animal's treatment (suckling and earlyweaned lambs).

The effects were tested against residual mean-squares to determine level of significance. Computations were performed using SPSS 14.0 software (SPSS Inc., Chicago, IL, USA).

\section{Results and discussion}

The suckling lambs slaughtered at 60 days of age did not exceed body weight required for light lambs (17-22 kg) in Poland. The average body weight of early-weaned lambs slaughtered at 90 days of age was over $6 \mathrm{~kg}$ higher (Table 2).

Table 2

Growth rate of suckling and early-weaned lambs

\begin{tabular}{lcccc}
\hline & $\begin{array}{c}\text { Suckling } \\
\text { lambs }\end{array}$ & $\begin{array}{c}\text { Early-weaned } \\
\text { lambs }\end{array}$ & $\begin{array}{c}\text { Standard } \\
\text { error }\end{array}$ & $\begin{array}{c}\text { Statistical } \\
\text { significance }\end{array}$ \\
\hline Birth body weight, kg & 4.97 & 5.41 & 0.24 & $\mathrm{~ns}$ \\
Body weight at 60 days, kg & 21.67 & 20.86 & 0.82 & $\mathrm{~ns}$ \\
Daily gain between 1st and 60th day, g/day & 297.11 & 284.88 & 17.46 & $\mathrm{~ns}$ \\
Body weight at 90 days, kg & - & 27.88 & 1.00 & \\
Daily gain between 60th and 90th day, g/day & - & 210.27 & 12.61 & \\
\hline
\end{tabular}

ns: not significant

The differences of total lipids content were not statistically significant in both groups of lambs (Table 3). The greater ages and weights are not always associated with higher intramuscular fat content, what has been also reported by Oriani et al. (2005) and Marino et al. (2008). The lack of markedly increase of total lipids in older lambs may be due to growth rate decrease after weaning (Table 2).

The fatty acid composition in intramuscular fat of suckling and early-weaned lambs is reported in Table 3. Meat from longissimus lumborum muscle of early weaned lambs had a higher content $(P \leq 0.01)$ of $C 16: 0$ and C15:0, and lower content $(P \leq 0.01)$ of $C 12: 0, C 14: 0$ than suckling lambs. The higher amount of palmitic acid (C16:0) in meat of older lambs has been also reported by Cifuni et al. (2000). The higher C12:0 and C14:0 content could be due to their appreciable amount in ewe's milk (Table 1), which suckling lambs used until slaughter. The 
greater value of C15:0 in early-weaned group of lambs could be related with development of ruminal microflora, as those odd-numbered carbon atoms fatty acids are originated from bacterial lipids (Jenkins 1993).

Table 3

Total lipids ( $\mathrm{g} / 100 \mathrm{~g}$ muscle tissue (fresh matter)) and fatty acid composition ( $\mathrm{g} / 100 \mathrm{~g}$ fat) of longissimus lumborum of suckling and early-weaned lambs

\begin{tabular}{lcccc}
\hline & $\begin{array}{c}\text { Suckling } \\
\text { lambs }\end{array}$ & $\begin{array}{c}\text { Early-weaned } \\
\text { lambs }\end{array}$ & $\begin{array}{c}\text { Standard } \\
\text { error }\end{array}$ & $\begin{array}{c}\text { Statistical } \\
\text { significance }\end{array}$ \\
\hline Total lipids & 2.15 & 2.32 & 0.25 & $\mathrm{~ns}$ \\
C10:0 & 0.05 & 0.08 & 0.01 & $\mathrm{~ns}$ \\
C12:0 & 0.51 & 0.36 & 0.03 & $* *$ \\
C14:0 & 4.35 & 3.80 & 0.12 & $* *$ \\
C15:0 & 0.56 & 0.69 & 0.03 & $* *$ \\
C16:0 & 22.30 & 23.71 & 0.28 & $* *$ \\
C17:0 & 1.12 & 1.01 & 0.05 & $\mathrm{~ns}$ \\
C18:0 & 16.37 & 16.02 & 0.18 & $\mathrm{~ns}$ \\
C14:1 & 0.50 & 0.52 & 0.01 & $\mathrm{~ns}$ \\
C15:1 & 0.33 & 0.32 & 0.01 & $\mathrm{~ns}$ \\
C16:1 & 2.72 & 2.42 & 0.10 & $*$ \\
C17:1 & 0.75 & 0.52 & 0.04 & $* *$ \\
C18:1 n-7 & 0.90 & 0.68 & 0.04 & $* *$ \\
C18:1 n-9 & 31.74 & 31.42 & 0.33 & $\mathrm{~ns}$ \\
C18:1 t11 (TVA) & 2.31 & 2.71 & 0.05 & $* *$ \\
C20:1 & 0.11 & 0.15 & 0.01 & $* *$ \\
C18:2 n-6 & 5.04 & 4.72 & 0.10 & $*$ \\
C18:2 c9,t11 (CLA) & 0.36 & 0.59 & 0.02 & $* *$ \\
C18:3 n-3 & 1.36 & 0.98 & 0.04 & $* *$ \\
C20:3 n-3 & 0.17 & 0.21 & 0.01 & $* *$ \\
C20:4n-6 & 1.11 & 1.09 & 0.04 & $\mathrm{~ns}$ \\
C20:5 n-3 (EPA) & 0.54 & 0.42 & 0.02 & $* *$ \\
C22:5 n-3 (DPA) & 0.51 & 0.36 & 0.02 & $* *$ \\
C22:6 n-3(DHA) & 0.17 & 0.16 & 0.01 & $\mathrm{~ns}$ \\
\hline
\end{tabular}

ns: not significant, ${ }^{*} P \leq 0.05,{ }^{*} P \leq 0.01$, TVA: trans vaccenic acid, CLA: conjugated linoleic acid, EPA: eicosapentaenoic acid, DPA: docosapentoic acid, DHA: docasahexaenoic acid

The highest amount from among monounsaturated fatty acids in intramuscular fat of suckling and early-weaned lambs was obtained for oleic acid (C18:1c9) (Table 3). However, the statistical differences between these groups of lambs have not been significant. The greater content of other monounsaturated fatty acids C16:1 $(P \leq 0.05), C 17: 1$ and C18:1 n-7 $(P \leq 0.01)$ has been noted in younger lambs (Table 3$)$. The monounsaturated fatty acids except it, that effectively reducing plasma cholesterol (Castelli 1993, Renner 1995), together with other fatty acids determines firmness/oiliness and oxidative stability of muscle, which affects juiciness, flavour and muscle colour (Wood et al. 2008).

The content of linolenic (C18:3), eicosapentaenoic (EPA), docosapentoic (DPA) fatty acids was higher $(P \leq ., 01)$ in longissimus lumborum muscle of suckling lambs than early weaned, slaughtered at 90 -days (Table 3). The similar results have been reported by Cifuni et al. (2000) in intramuscular fat of 45 and 90-day-old lambs, as well as Marino et al. (2008) in lambs slaughtered at 42 and 70 days of age. 
In presented study, the source of long-chain fatty acids could be hay for C18:3 and concentrate for C18:2, given for lambs from two weeks of life. The higher content of these acids in suckling lambs could result from it, that they may not have the final ruminal microflora and dietary unsaturated fatty acids could be bacterially modified in less extend than in early weaned lambs and unchanged incorporated into tissues (Jenkins 1993, Wood et al. 2008). Linolenic acid, originated from dietary lipids, could allow the endogenous synthesis of long-chain PUFA by elongase and desaturase activities. C18:3 is a precursor of long-chain n-3 fatty acids such as EPA, DPA and DHA (White 1995).

The suckling lambs slaughtered at 60 days of age presented higher amount of unsaturated fatty acids ( $P \leq 0.01)$, especially PUFA $(P \leq 0.01)$ and had better PUFA/ saturated fatty acid $(P \leq 0.01)$ ratio than early weaned lambs, slaughtered at older age (Table 4). This is in accordance with Nuernberg et al. (1998) hypothesis, that PUFA decrease with age.

Table 4

Fatty acid classes, relations and indexes ( $\mathrm{g} / 100 \mathrm{~g}$ fat) of logissimus lumborum muscle and TBA-RS value (nmol/ $\mathrm{ml}$ serum) in blood serum of suckling and early-weaned lambs

\begin{tabular}{|c|c|c|c|c|}
\hline & Suckling lambs & Early-weaned lambs & Standard error & Significance \\
\hline SFA & 45.26 & 45.67 & 0.36 & ns \\
\hline MUFA & 39.36 & 38.74 & 0.36 & ns \\
\hline PUFA & 9.27 & 8.53 & 0.12 & $* *$ \\
\hline UFA & 48.62 & 47.27 & 0.35 & $* *$ \\
\hline$n-3$ & 2.75 & 2.13 & 0.06 & $* *$ \\
\hline$n-6$ & 6.15 & 5.81 & 0.09 & ns \\
\hline UFA/SFA & 1.08 & 1.04 & 0.02 & ns \\
\hline MUFA/SFA & 0.87 & 0.85 & 0.01 & ns \\
\hline PUFA/SFA & 0.20 & 0.19 & 0.00 & $* *$ \\
\hline$n-6 / n-3$ & 2.24 & 2.75 & 0.07 & $* *$ \\
\hline C18:2 c9,t11 /C18:1 t11 & 0.17 & 0.24 & 0.01 & $* *$ \\
\hline $\mathrm{TI}$ & 1.37 & 1.50 & 0.02 & $* *$ \\
\hline $\mathrm{Al}$ & 0.56 & 0.60 & 0.01 & ns \\
\hline TBA-RS & 1.51 & 1.32 & 0.06 & ns \\
\hline
\end{tabular}

ns: not significant, ${ }^{*} P \leq 0.05, \quad{ }^{*} P \leq 0.01$, SFA: saturated fatty acids $(C 10: 0+C 12: 0+C 14: 0+C 15: 0+C 16: 0+17: 0+C 18: 0)$, MUFA: monounsaturated fatty acids (C14:1+C15:1+C16:1+C17:1+C18:1n-7+C18:1n-9+C20:1+C18:1t11 TVA), PUFA: polyunsaturated fatty acids (C18:2+C18:3+C20:3+C20:4+C20:5+C22:5+C22:6+C18:2C9,t11), UFA: unsaturated fatty acids (MUFA+PUFA), n-3: (C18:3+C20:3+C20:5+C22:5+C22:6), n-6: (C18:2+C20:4), Tl: thrombogenic index (C14:0+ C16:0+C18:0/ 0.5 SMUFA+0.5 SPUFA n-6+3 SPUFA n-3+n-3/n-6) (Ulbricht \& Southgate 1991), Al: atherogenic index (C12:0+4 x C14:0+C16:0/ SMUFA+SPUFA n-6 and n-3) (Ulbricht \& Southgate 1991)

Furthermore, C20:4 (AA) and C20:5 (EPA) are precursors to synthesis of eicisanoides like prostaglandines (PGE), prostacyclines (PGI), tromboxanes (TXA) and leucotrienes (LT). The PGE2, PGI2 TXA2 and LT4 are synthesised from n-6 fatty acid, whereas PGE3, PGI3 TXA3 and LT5 from n-3 fatty acid. The 2- and 4-series PGE/PGI/TXA/LT may contribute stimulation of proliferation processes, while 3- and 5-series PGE/PGI/TXA/LT have ability to inhibit of these processes (Gill \& Valivety 1997, Grimble 1998) Thus, lowering $n-6 / n-3$ ratio in human diet is very advisable. The amount of $n-3$ fatty acid was higher $(P \leq 0.01)$ in meat tissue of suckling lambs, than in early weaned ones. Also n-6/n-3 ratio was lower $(P \leq 0.01)$ and at the same better in longissimus lumborum muscle of suckling lambs (Table 4). This group of lambs, compared to early weaned was characterised by lower $(P \leq 0.01)$ value of thrombogenic index 
(Table 4). The better value of thrombogenic index for younger lambs ( $42 \mathrm{vs.} 70$ days) has been also reported by Marino et al. (2008).

The early-weaned lambs were characterised by higher c9,t11 C18:2 $(P<0.01)$ content than suckling lambs (Table 3). This isomer could originate from the rumen, where is formed by biohydrogenation from alimentary PUFAs than directly incorporated to tissues, and from endogenous synthesis within tissues. In the tissues c9,t11 C18:2 is synthetised by $\Delta 9$ desaturase from vaccenic acid (Kay et al. 2002, Piperova et al. 2002, Khanal \& Dihman 2004). The higher amount of vaccenic acid $(P \leq 0.01)$ (Table 3$)$ and higher $C 18: 2 \mathrm{C} 9, \mathrm{t} 11 / \mathrm{C} 18: 1 \mathrm{t} 11$ ratio $(P \leq 0.01)$ (Table 4), which expresses $\Delta 9$ desaturase activities, indicates enhanced de novo synthesis of conjugated linoleic acids in tissues of early weaned lambs, slaughtered at 90 days of age. The source of vaccenic acid, as a precursor for that synthesis, could be extended hydrogenation of C18 dietary fatty acids by better functioning rumen microflora in early-weaned lambs.

The higher proportion of c9,t11C18:2 is desirable in human diet. This isomer is the most biologically active conjugated linoleic acids isomer and has positive effect on preventing cancer, cardiovascular disease, diabetes and immune system (Pariza et al. 2001, Lock et al. 2004, O'Shea et al. 2004, Terpstra 2004).

The differences of TBARS value in serum of suckling and early-weaned lambs have not been statistically significant (Table 4). However, the TBARS value of serum tended to decrease in early-weaned lambs. The tendency to lower oxidation, estimated not in serum but in meat, has been observed for older lambs by Cifuni et al. (2000).

In conclusion, the observed differences of fatty acid profile in longissimus lumborum muscle of suckling and early-weaned lambs can be attributed to different physiological condition and digestive capabilities of the animals.

The not finally developed ruminal microflora of suckling lambs has made possible exogenous long-chain fatty acids incorporation into muscle lipids. These lambs had the higher value of $n-3$ fatty acids and lower $n-6 / n-3$ ratio. Than at lambs with better functioning rumen microflora, the higher amount of vaccenic acid, which is essential to endogenous synthesis of rumenic acid, has been obtained. The content of c9,t11 C18:2 isomer was higher in early-weaned lambs.

Thus, the both groups of lambs were characterised by fatty acid profile compatible with good health and nutrition of consumers.

\section{References}

AOAC (Association of Official Analytical Chemists) (1990) Food Composition Additives, Natural Contaminants. 15th ed., Arlington, TX, USA, 963

Burns CP, Spector AA (1994) Biochemical effects of lipids on cancer therapy. J Nutr Biochem 5, 114-123

Castelli WP (1993) The fact and fiction of lowering cholesterol concentrations in the primary prevention of coronary heart disease. Br Heart J 69 (Suppl.), S70-S73

Cifuni GF, Napolitano F, Pacelli C, Riviezzi MA, Girolami A (2000) Effect of age at slaughter on carcass traits, fatty acid composition and lipid oxidation of Apulian lambs. Small Rum Res 35, 65-70

Calder PC (1998) Fat chance of immunomodulation. Immunol Today 19, 244-247

Díaz MT, Velasco S, Cañegue V, Lauzurica S, de Huidobro FR, Pérez C, Gonzáles J, Manzanares C (2002) Use of concentrate or pasture for fattening lambs and its effect on carcass and meat quality. Small Rum Res 43, $257-268$ 
Díaz MT, Velasco S, Pérez C, Lauzurica S, de Huidobro FR, Cañegue V (2003) Physico-chemical characteristics of carcass and meat Manchego-breed suckling lambs slaughtered at different weights. Meat Sci 65, $1247-1255$

Fernandez G, Venkatraman JT (1993) Role of omega-3 fatty acids in health and disease. Nutr Res 13 (Suppl.), S19-S45

Folch J, Lees M, Sloane Stanley GH (1957) A simple method for the isolation and purification of total lipides from animal tissues. J Biol Chem 266, 497-509

Gill I, Valivety R (1997) Polyunsaturated fatty acids, Part I: Occurrence, biological activities and applications. Trends Biotechnol 15, 401-409

Grimble RF (1998) Modification of inflammatory aspects of immune function by nutrients. Nutr Res 18 , 1297-1317

Hu FB, Stampfer MJ, Marson JE, Aschiero A, Colditz GA, Speizer FE, Hennekens CH, Willet WC (1999) Dietary saturated fats and their food sources in relation to the risk of coronary heart disease in women. Am J Clin Nutr 70, 1001-1008

Jenkins TC (1993) Lipid metabolism in the rumen. J Dairy Sci 76, 3851-3863

Kay JK, Mackle TR, Auldist MJ, Thomson NA, Bauman DE (2002) Endogenous synthesis of cis-9, trans-11 conjugated linoleic acid in pasture-fed dairy cows. J Dairy Sci 85 Suppl. 1, 176

Khanal RC, Dihman TR (2004) Biosynthesis of conjugated linoleic acid (CLA): a review. Pak J Nutr 3, 72-81

Kramer JKG, Fellner V, Dugan MER, Sauer FD, Mossoba MM, Yurawecz P (1997) Evaluating acid and base catalysts in the methylation of milk and rumen fatty acids with special emphasis on conjugated dienes and total trans fatty acids. Lipids 32, 1219-1228

Kritchevsky D (1998) History of recommendations to the public about dietary fat. J Nutr 128, 449-452

Lock A, Corl LBA, Barbano DM, Bauman DE, Ip C (2004) The anticarcinogenic effect of trans-11 18:1 is dependent on its conversion to cis-9, trans-11 CLA by D9- desaturase in rats. J Nutr 134, 2698-2704

Marino R, Alberizio M, Annicchiarico G, Caroprese M, Muscio A, Santillo A, Sevi A (2008) Influence of genotype and slaughtering age on meat from Altamurana and Trimeticcio lambs. Small Rum Res 78, 144-151

Nair V, Turner GA (1984) The thiobarbituric acid test for lipid peroxidation: structure of the adduct with malondialdehyde. Lipids 19, 804-805

Nuernberg K, Wegner J, Ender K (1998) Factors influencing fat composition in muscle and adipose tissue of farm animals. Livest Prod Sci 56, 145-156

Oriani G, Maiorano G, Filetti F, Di Cesare C, Manchisi A, Salvatori A (2005) Effect of age on fatty acid composition of Italian Merino suckling lambs. Meat Sci 71, 557-562

O'Shea M, Bassaganya-Riera J, Mohede ICM (2004) Immunomodulatory properties of conjugated linoleic acid. Am J Clinic Nutr 79 (Suppl.), S1199-S1206

Pariza MW, Park Y, Cook ME (2001) The biologically active isomers of conjugated linoleic acid. Progr Lipid Res 40, 283-298

Pearson AM, Gray J, Wolzak AM, Horenstein NA (1983) Safety implications of oxidized lipids in muscle foods. Food Technol 37, 121-129

Piperova LS, Sampugna J, Teter BB, Kalscheur KF, Yurawecz MP, Ku Y, Morehouse KM, Erdman RA (2002) Duodenal and milk trans octadecenoic acid and conjugated linoleic acid (CLA) isomers indicate that postabsorptive synthesis is the predominant source of cis-9-containing CLA in lactating dairy cows. J Nutr $132,1235-1241$

PN-EN ISO 5508 (1996) [Vegetable and animal oils and fats. Analysis of methylesters of fatty acids]. [in Polish]

PN-EN ISO 5509 (2001) [Vegetable and animal oils and fats. Preparation of methylesters of fatty acids]. [in Polish]

Renner E (1995) Importance of milk and its different components for human nutrition and health. Proc. NJF/ NMR Seminar No. 252, Turku, Finland, 7-22 
Rhee KS, Lupton CJ, Ziprin YA, Rhee KC (2003) Carcass traits of Ramboulliet and Merino $\times$ Ramboulliet lambs and fatty acid profiles of muscle and subcatneous adipose tissues as affected by new sheep production system. Meat Sci 65, 693-699

Schmid A, Collomb M, Sieber R, Bee G (2006) Conjugated linoleic acid in meat and meat products: a review. Meat Sci 73, 29-41

SPSS (2005) User's Guide 14.0. SPSS Inc., Chicago, IL, USA

Terpstra AH (2004) Effect of conjugated linoleic acid of body composition and plasma lipids in humans: an overviev of the literature. Am J Clin Nutr 79, 325-361

Ulbricht TLV, Southgate DAT (1991) Coronary heart disease: seven dietary factors. Lancet 338, 985-992

Wachira AM, Sinclair LA, Wilkinson RG, Enser M, Wood JD, Fisher AV (2002) Effect of dietary fat source and breed on the carcass composition. n-3 polyunsaturated fatty acid and conjugated linoleic acid content of sheep meat and adipose tissue. Br J Nutr 88, 697-709

White $P$ (1995) Essenatial fatty acids in veterinary medicine. Bayer AG, Leverkusen, Germany

Williams C (2000) Dietary fatty acids and human health. Ann Zoot 49, 165-180

Wood JD, Enser M (1997) Factors influencing fatty acid in meat and the role of antioxidants in improving meat quality. Br J Nutr 78 (Suppl.), S49-S60

Wood JD, Enser M, Fisher AV, Nute GR, Sheard PR, Richardson RI, Hughes SI, Whittington FM (2008) Fat deposition, fatty acid composition and meat quality: A review. Meat Sci 78, 343-358

Received 30 June 2011, accepted 7 February 2012.

Corresponding author:

Aurelia Radzik-Rant

email: aurelia_radzik_rant@sggw.pl

Department of Animal Breeding, Faculty of Animal Science, Warsaw University of Life Sciences, Ciszewskiego 8, 02-786 Warsaw, Poland 